\title{
Eliminating Indirect Energy Subsidies in Ukraine: Estimation of Environmental and Socioeconomic Effects Using Input-Output Modeling
}

\author{
Iuliia Ogarenko • Klaus Hubacek
}

Received: 24 September 2012 / Accepted: 27 August 2013 / Published online: 11 September 2013 (C) 2013 I. Ogarenko, K. Hubacek; licensee Springer. This is an Open Access article distributed under the terms of the Creative Commons Attribution License (http://creativecommons.org/licenses/by/2.0), which permits unrestricted use, distribution, and reproduction in any medium, provided the original work is properly cited.

\begin{abstract}
Energy subsidies are causing adverse effects on the economy and environment stimulating inefficient resource allocation and excessive energy consumption. Therefore, multiple positive effects are likely to be obtained if subsidies are reduced or removed completely. This study estimates indirect end-user energy subsidies in gas and electricity sectors of Ukraine and assesses short-term environmental and socioeconomic effects of a hypothetical elimination of these subsidies. Consumer subsidies are quantified utilizing the price-gap approach that compares end-user prices and reference prices that would predominate in competitive markets where no subsidies are provided. Input-output analysis is undertaken to investigate impacts in the short-term. First, a price model is utilized to estimate price changes resulting from subsidy elimination and then a demand-driven IO model is adopted for estimation of associated changes of environmental and social variables. As a result of elimination of energy subsidies, total energy consumption and GHG emissions would decline by about $2.5 \%$ and $3.6 \%$, respectively. In addition, distributional effects of a subsidy reform are analyzed utilizing data on consumption patterns of different income groups.
\end{abstract}

Keywords Energy subsidies · Input-output modeling · Price-gap approach · Ukraine $\cdot \mathrm{CO}_{2}$

JEL Classification D57 · P22 · P28 · Q41

Electronic supplementary material The online version of this article (doi:10.1186/2193-2409-2-7) contains supplementary material.

I. Ogarenko $(\bowtie)$

Institute for Economic Research and Policy Consulting, Reytarska str. 8/5-A, 01034, Kyiv, Ukraine e-mail: ogarenko@ier.kiev.ua

K. Hubacek

Department of Geographical Sciences, University of Maryland, College Park, MD 20782, USA

e-mail: hubacek@umd.edu 


\section{Introduction}

In order to mitigate climate change and accelerate transition toward a more sustainable development path, massive investments are required for energy efficient and renewable energy technologies. Instead, large amounts of money are spent annually to stimulate production and consumption of conventional energy. Governments provide support either explicitly through subsidies or implicitly through interventions in energy prices and fuel allocation. Theoretically, subsidies could be justified if they increase overall social welfare. However, fossil-fuel subsidies are seen as having a net negative effect since they distort the economy and stimulate environmental deterioration (Ellis 2010). Although in OECD countries energy subsidies have decreased considerably over the past two decades, subsidies are still pervasive in developing countries and transition economies (UNEP 2004).

Direct state support for energy sectors is not large in Ukraine compared to very high implicit subsidies due to under-pricing of energy products. Gas, electricity, and district heating tariffs for households are set by the state at very low rates, which do not reflect full costs for maintenance and capital investments (IEA 2006b). Underpricing of energy distorts the economy of Ukraine and is one of the most important factors of its persistently high energy-intensity. As of 2009, it was at the level of 0.40 Total Primary Energy Supply (TPES)/GDP (ppp) (toe per 1000 USD at 2000 prices) compared to 0.37 for non-OECD Europe and Eurasia and a world average of 0.19TPES/GDP (ppp) (IEA 2011a). Energy consumption is also responsible for a large share of GHG emissions of the country. In particular, GHG emissions from fuel combustion amounted to 240.6 million tons $\mathrm{CO}_{2}$-eq., i.e., $57 \%$ of the total country emissions in 2008 (MENR 2010).

In the early 1990s, GHG emissions of the country had fallen drastically as a result of the collapse of the Soviet Union and resultant crash of the national economy with a GDP drop of about $50 \%$ (SSCU 2009a) in 1995 compared to 1990 levels. Nevertheless, Ukraine is among the top 20 largest $\mathrm{CO}_{2}$ emitters in the world (United Nations Statistics Division 2010), with one of the highest carbon intensities of $0.89 \mathrm{~kg} \mathrm{CO}_{2}$ eq/GDP (PPP), which is slightly higher than for non-OECD Europe and Eurasia, but almost twice as large as the world average (IEA 2011a).

Since the mid-1990s, the economy has gradually recovered and GHG emissions have started to rise. However, in situations of frequent political instability and heavy economic and social problems, environmental issues and climate change in particular are far from being a priority on the political agenda.

A number of modeling studies show evidence that reduction or elimination of energy subsidies could bring environmental and economic gains (for a good review, see Ellis 2010). Similarly, the IEA (1999) suggests that elimination of energy subsidies is likely to address all three dimensions of sustainable development. Environmental benefits would be obtained through efficient pricing leading to reductions of environmental pollution. Social welfare could be improved by redirecting public funds spent on subsidies toward social needs. Economic advantages could be derived from increased efficiency of resource allocation and reduced public expenditures.

A number of studies have been undertaken to estimate environmental and economic impacts of phasing out energy subsidies in developing and transition 
economies (e.g., Saboochi 2001; Saunders and Schneider 2000; Lin and Jiang 2011). However, according to our knowledge, no papers have previously analyzed the likely effects of the removal of end-user energy subsidies (i.e., energy price distortions) for the Ukrainian context. In addition, conclusions derived for Ukraine could also be relevant for other transition economies since the majority of post-Soviet countries inherited highly energy-intensive economies due to relative abundance of energy resources in the Soviet Union and state control of energy prices. Therefore, the objective of this study is to estimate end-user energy subsidies in gas and electricity sectors of Ukraine and assess environmental and socioeconomic effects of a hypothetical elimination of energy subsidies.

The paper does not consider direct subsidies (i.e., direct payments made by the government) either to consumers or producers but focuses on implicit consumer subsidies following the definition and approach of the International Energy Agency (1999). We adopted a broad definition of energy subsidies as any government policies or measures could directly or indirectly influence prices or costs. These subsidies are estimated as a price-gap between actual prices and market prices, which would prevail in the absence of subsidies. In this paper, we focus only on consumer subsidies in electricity and gas sectors. Indirect consumer subsidies for the oil and coal sector are not considered since previous studies have shown that prices of oil products are close to market levels and consumer subsidies for coal did not take place in Ukraine (e.g., IEA 2006a, 2008, 2011b).

Section 2 provides an overview of the previous estimates of energy subsidies in Ukraine and reviews the literature for environmental and socioeconomic effects of a hypothetical subsidy reform. Section 3 elucidates theoretical underpinnings of the price-gap approach and input-output analysis, describes the data utilized in the analysis, and points out limitations of this paper. Section 4 presents the main findings of the study. Finally, conclusions and policy implications of the hypothetical energy subsidy reform are summarized in Sect. 5.

\section{An Overview of Previous Estimates of Energy Subsidies in Ukraine and Impact Assessments of Removal of Subsidies}

First estimations of energy subsidies for developing countries and economies in transition are dating back to the 1990s. For example, the pioneering study by Larsen and Shah (1992) estimated energy subsidies in the countries of the former Soviet Union amounting to 172 billion USD. However, only few estimates have been carried specifically for Ukraine. Perhaps, the first one and the most detailed to date is the case study prepared by Petri et al. (2002) that computed quasi-fiscal activities in gas and electricity sectors being equal to $6.5 \%$ of GDP in 2000. Saavalainen and Berge (2006) calculated the quasi-fiscal deficit for the same sectors as being $5.3 \%$ and $3.1 \%$ of GDP, respectively. Legeida (2001) analyzed both explicit and implicit subsidies in Ukraine's economy in 2000. IEA (2006a, 2008) calculated consumer energy subsidies from under-pricing for the 20 largest non-OECD countries. According to IEA's estimates, in Ukraine subsidies for gas consumption reached about 12 billion USD in 2005 and 10 billion USD in 2007. Subsidies for electricity were significantly lower, 2.5 billion USD in 2005 and around 4 billion USD in 2007. 
Estimation of macroeconomic effects of energy price shocks is an important and a well-established field of research; numerous studies have been carried out to investigate effects of steep increases of energy prices at the international and regional level as well as for individual countries (e.g., Bohi 1991; IEA 2004; Lardic and Mingnon 2006; Nasseh and Elyasiani 1984; World Bank 2005). The gas conflict between Russia and Ukraine in 2006 and resultant abrupt price increase of imported gas stimulated research on the effects of energy price shocks on Ukraine's economy. For example, the Institute for Economic Research and Policy Consulting (IER) in Ukraine (2006) estimated, using a Computable General Equilibrium (CGE) model, that an increase of the gas price by $60 \%$ triggered by a sharp price increase of imported gas could result in an annual $5.5 \%$ decline of real GDP and about a $20 \%$ decrease of total welfare in the medium-term (about 7-10 years) after the economy has fully adjusted to the external price shock. Chemical industry and metallurgy are expected to be the most vulnerable with about $80 \%$ decline of aggregate output. It has been estimated that in order to mitigate the effect of a large price increase, i.e., prevent the drop of real GDP, domestic gas consumption should be reduced by $36 \%$, which equals a $12 \%$ decline of the energy-intensity of the economy. Another study by IER (2007) has shown that energy market reforms coupled with investment in energy efficiency and expansion of domestic gas production could counteract negative effects of energy price shocks. In particular, an approximate three times increase of the domestic price of gas and about 2 times for electricity and heat could reduce total primary energy supply (TPES) by about $50 \%$ over a 10-year time horizon.

A World Bank (2005) study utilized a simple Net Import Model to quantify shortterm effects of oil and gas price shocks on Ukraine's economy. Depending on the scenarios employed, GDP would decline within the range of 0.4-8.6\% for the first year of the price shock and $0.2-6 \%$ of GDP during the second year. Flanagan et al. (2007) used statistical modeling to quantify effects of a $10 \%$ increase in the import price of gas over the short and medium-term period. In the near term (1 year), output could decline from $0.09 \%$ to $0.43 \%$ (depending on the method) and inflation could increase by up to $1.17 \%$. Mid-term effects on output would be higher (from $0.47 \%$ to $0.50 \%$ ) while inflation rate could decrease to $1.06 \%$.

In spite of all modeling estimates, Ukraine's economy has proven to be more resilient to external price shocks than expected. GDP growth remained positive in 2006 and even counteracted declining tendencies recorded in 2005 (Pirani 2007). The author notes that the main reasons for this are high prices of exporting products, particularly metals, energy efficiency improvements, and consumption-induced growth of the economy.

Historically, energy subsidies have been introduced to ameliorate important social issues; however, it might not have been the most efficient method to address them. The only case when energy subsidies could be justified is when increasing energy production and consumption beyond economically efficient levels is the only possible way to achieve important policy targets, which is very difficult to prove in reality. In fact, direct transfer of funds could be a more efficient approach to deal with social problems than subsidizing energy consumption (IEA 1999). For example, Kebede (2006) examined the effectiveness of energy subsidies for kerosene and electricity in Ethiopia and came to the conclusion that subsidies benefit more nonpoor households than low income groups. 
Similar to carbon pricing policies, removal of subsidies is likely to have negative distribution effects (Feng et al. 2010; Kerkhof et al. 2008) since low income groups are usually spending a larger share of their income on utilities, which would increase prices considerably if gas and electricity subsidies are abolished. A number of studies were carried out previously to examine distributional effects of energy subsidy reform in developing countries (Gangopadhyay et al. 2005; Kebede 2006; Parvin and Banouei 2009; Soheir et al. 2009). For example, Saboohi (2001) found evidence that negative effects could be minimized and net income of the poor in Iran could even increase if the energy subsidy reform is accompanied by a mechanism of recycling back of some revenues to lower income households.

A limited amount of literature is available on the affordability of basic utility services and susceptibility of price increases for low-income households in transition countries (e.g., Fankhauser and Tepic 2007; Fankhauser et al. 2008; Lampietti et al. 2001; Lampietti and Meyer 2002; Lovei et al. 2000). Dodonov et al. (2004) examined vulnerability of poor households in Ukraine to increases of electricity tariffs and came to conclusion that adjusting electricity prices up to cost-covering levels estimated by the National Electricity Regulation Commission (NERC) would not cause considerable welfare losses for households. However, the authors claim that further increases up to the average OECD levels, to reflect long-run marginal production costs, could have adverse social consequences and should be implemented in a stepwise fashion.

Elimination of subsidies is the initial step for establishing the level of emissions at the "socially optimal level" with the subsequent implementation of carbon pricing policies aiming to internalize externalities (World Bank 1997). However, in situations when energy prices simply do not reflect opportunity costs or long-run marginal production costs in developing countries and economies in transition, phasing out energy subsidies alone could be perceived as effective climate mitigation policy. Since energy consumption and GHG emissions are intrinsically coupled, a price-induced decrease of energy use would eventually result in reduction of GHG emissions. For example, Burniaux et al. (2009) estimated using the OECD ENV-Linkages model that gradual elimination of subsidies over the period from 2013 to 2020 (assuming no other mitigation policies are taken) would result in a $\sim 20 \%$ reduction in $\mathrm{CO}_{2}$ emissions in Russia and other non-EU Eastern European countries.

\section{Methodology}

\subsection{Price-Gap Approach}

The underlying presumption of the price-gap approach is that energy subsidies decrease prices of energy goods and services, thereby, leading to increase in consumption. The "price gap" is the difference between final consumer prices and reference prices that would dominate in competitive markets where no subsidies are provided to either consumers or producers (IEA 1999). Theoretical underpinnings of the methodology were developed by Corden (1957). Larsen and Shah (1992) applied the pricegap approach for quantification of global fossil-fuel consumption subsidies. Later, the method was used by the IEA $(1999,2006 a, 2006 b, 2008)$ for estimation of energy subsidies in the largest non-OECD countries. 
The price-gap approach is described in detail by IEA (1999). The basic idea to compare end-user energy prices with reference prices is very simple; however, practical application of the method is less straightforward since some assumptions need to be made for calculation of reference prices. End-user prices correspond to actual energy prices paid by final consumers. These prices reflect current energy pricing policy of a country and incorporate all taxes and fees as well as reductions and rebates imposed on energy products and services. Reference prices indicate the prices at undistorted market and reflect full opportunity cost of energy consumption. Either international market prices or long-run marginal cost of production could be used as a benchmark for reference prices of energy products. For traded goods, the reference price is calculated based on the export or import border price, for nontraded products, production cost forms the basis. Importantly, border price and domestic production cost should be equal to an 'ideal' competitive market. Domestic production cost should be estimated based at the international price even if the product could be produced domestically at the lower cost (OECD 2010). Internal transportation and distribution costs are also incorporated in the reference price. In addition, Value Added Tax (VAT) and other country-specific general transaction taxes should be included. These taxes "are part of the cost of doing business" and do not influence comparative prices between energy products and other goods, and hence, economic efficiency of resource allocation (p. 76 in IEA 1999). However, energy taxes should not be used for calculation of reference prices since they partly offset subsidy-induced effects on final prices and consumption. Therefore, subsidies for final energy and gas consumers in Ukraine are calculated utilizing the following equation:

$$
S_{\mathrm{c}}=Q\left(P_{\mathrm{r}}-P\right)
$$

where $S_{\mathrm{c}}$ is defined as consumer subsidies for gas or electricity, $P$-end-user price including subsidies, $P_{\mathrm{r}}$ - estimated reference price excluding subsidies and $Q$ - total consumption of gas or electricity. Final prices are differentiated depending on the consumer group, quantity of energy consumed (the price increases with higher energy consumption), and availability of meters. Since energy consumption data for each group of consumers (with different energy consumption and with or without meters) is not available at a very detailed (price differentiation) level, it was decided to compare actual cost, reported by the Ministry of Fuel and Energy (MFE 2009) and estimated reference cost for a given quantity of energy consumed. Thus, Eq. (1) could be presented in the following way:

$$
S_{\mathrm{c}}=C_{\mathrm{r}}-C_{\mathrm{a}}
$$

where $C_{\mathrm{a}}=P Q$ is defined as actual cost of gas or electricity consumed at the current end-user prices reported by the Ministry of Fuel and Energy of Ukraine (MFE 2009) and $C_{\mathrm{r}}=P_{\mathrm{r}} Q$ is defined as cost in an undistorted market. Reference price and cost for gas is estimated based on the price of imported gas and adjusted for transportation and distribution costs and $20 \%$ value added tax (VAT). A special surcharge coefficient on the gas price is also included since it works not as classical energy tax levied on energy to reduce energy consumption or emissions. On the contrary, the revenues generated by the surcharge are used for gasification of new territories 
and compensation of the losses of Naftogaz (holding the largest share of the oil and gas market in Ukraine) from selling gas to district heating companies. Therefore, the surcharge contributes to full costs of the product and investment needs, which should be included in prices of all goods and services. Hence, the surcharge does not distort relative prices between energy products and other goods. A special surcharge coefficient $^{1}$ is used as a coefficient on cost of gas excluding transportation and distribution tariffs and VAT. The duty aiming to compensate expenditures of Naftogaz on selling gas to households has also been included for the same reasons. Therefore, reference cost of gas, $C_{\mathrm{rg}}$ (in Ukrainian Hryvnia, $\mathrm{UAH}$ ) is expressed as

$$
C_{\mathrm{rg}}=Q_{\mathrm{g}}\left(P_{\mathrm{im}}+C_{\mathrm{s}}+T_{\mathrm{tg}}+T_{\mathrm{dg}}\right)(1+V A T)+S_{\mathrm{s}} Q_{\mathrm{g}}\left(P_{\mathrm{im}}+C_{\mathrm{s}}\right)
$$

where $Q_{\mathrm{g}}$ is total consumption of gas (in $1000 \mathrm{~m}^{3}$ ), $P_{\mathrm{im}}$ (in UAH per $1000 \mathrm{~m}^{3}$ ) is the price of gas at the border, $C_{\mathrm{s}}$ (in UAH per $1000 \mathrm{~m}^{3}$ ) — cost of selling gas incurred by Naftogaz, $S_{\mathrm{S}}$-special surcharge coefficient; $T_{\mathrm{tg}}$ and $T_{\mathrm{dg}}$ transportation and distribution tariffs (in UAH per $1000 \mathrm{~m}^{3}$ ), respectively. In 2008, the price of imported gas was at $945.5 \mathrm{UAH}$ per $1000 \mathrm{~m}^{3}$ which approximately equals $179.5 \mathrm{USD}^{2}$ Average 2008 values of other price components provided by the National Electricity Regulation Commission (NERC 2009) and Ministry of Fuel and Energy (2009) are used in estimates. Since Ukraine less actively participates in electricity trade (about $4 \%$ is exported according to NERC 2009) with other countries compared to other types of energy, long-term production cost is a more appropriate benchmark for estimation of subsidies than the export border price. According to NERC (2009), the wholesale market price (for suppliers) reflects all operational costs and incorporates surcharge for some investments. However, current tariffs are not high enough to compensate for depreciation and investment needs in nuclear, hydro, and most thermal power plants (IEA 2006b). According to the Energy Strategy of Ukraine (MFE 2006), the electricity sector requires around 196 billion UAH (37 billion USD) of investment during the period from 2006 to 2010, which means approximately 39 billion UAH ( 7 billion USD) annually. MFE (2009) reports that about 5 billion UAH (0.95 billion USD) of capital investment have been utilized by the energy sector from all sources (including surcharge) in 2008. Hence, investment deficit amounted to around 34 billion UAH ( 6.5 billion USD) or $0.27 \mathrm{UAH} / \mathrm{kWh}(0.05 \mathrm{USD} / \mathrm{kWh})$ for approximately 125 billion kWh of electricity consumed in 2008 (MFE 2009). Therefore, prices should be increased by about $0.27 \mathrm{UAH} / \mathrm{kWh}$ in order to reflect long-run production costs. This approach is especially relevant because the government perceives optimization of the price and tariff policy as one of the most important mechanisms of investment in the energy sector (MFE 2006). In addition, the wholesale price should be first adjusted to eliminate cross-subsidization of households by industrial consumers. The price used in calculations is reduced by $23.7 \%$ (proportion of cross-subsidization) (NERC 2009). Therefore, reference cost of electricity $C_{\text {re }}$ (in UAH) is calculated as follows:

$$
C_{\mathrm{re}}=Q_{\mathrm{e}}\left(P_{\mathrm{w}}+I_{\mathrm{d}}+T_{\mathrm{te}}+T_{\mathrm{se}}\right)(1+V A T)
$$

\footnotetext{
${ }^{1}$ Decree of Cabinet of Ministers of Ukraine N 442 as of 11 June 2005 on the special surcharge on gas tariff.

${ }^{2}$ Decree of Cabinet of Ministers of Ukraine N 163 as of 5 March 2008 on selling imported natural gas in Ukraine.
} 
where $Q_{\mathrm{e}}$-total electricity consumed (in $\mathrm{kWh}$ ), $P_{\mathrm{W}}$ - wholesale price for suppliers (in UAH/kWh), $I_{\mathrm{d}}$-investment deficit (in UAH/kWh), $T_{\mathrm{te}}$ and $T_{\mathrm{se}}$ - transmission and supply tariffs for electricity (in UAH/kWh). Average 2008 prices and tariffs in the electricity sector published by National Electricity Regulation Commission (NERC 2009) are used in the estimates.

Despite the fact that price-gap metric is widely applied for cross-country studies (e.g., Burniaux et al. 1992; IEA 1999; Larsen and Shah 1992), due to its relative simplicity and low level of data requirements, it has a number of important limitations described by Koplow (2009) and IEA (1999).

\subsection{Estimating Price Effects on Environmental and Socioeconomic Factors}

\subsubsection{Input-Output (IO) Price Model}

Input-output analysis is carried out for estimation of environmental and socioeconomic effects from phasing-out energy subsidies in the gas and electricity sectors of Ukraine. We have chosen IO approach because it is a well established and the most transparent methodology appropriate for addressing research questions set in this paper. As demonstrated in Ginsburgh and Keyzer (1997), input-output models can be regarded as simplified general equilibrium models or satisfactory approximation to general equilibrium models when the modeling focus is on short-term analyses of one-shot policy shocks like the price-gap elimination specified in this paper. In addition, this study utilizes both the demand-driven and price IO model to establish the link between changes of relative prices and quantities of goods demanded, thus incorporating the essence of a CGE model without burdening itself with the complex and data-demanding work of constructing a fully fledged CGE model. While a CGE model is capable of assessing structural and technological change effects of policy shocks, this study argues that it is important to study short-run consequences for the purpose of developing mitigation strategies as unwillingness to encounter additional costs usually impedes necessary policy reforms. Another advantage of the IO methodology is that it allows explicitly examining industry interdependency, in the case of this research, how elimination of subsidies in gas and electricity sectors triggers changes in other sectors.

The study builds on the dual nature of the input-output system and utilizes both the demand-driven and price IO model. In addition, partial equilibrium analysis is incorporated within an IO framework to establish the link between changes of relative prices and quantities of goods demanded.

The Leontief price model is the starting point of the analysis. The model reflects that the total price of one unit of output is equal to total costs of its production including intermediate purchases and primary inputs. Thus, the basic equation of the Leontief price model is usually expressed as follows:

$$
\mathbf{p}^{\prime}=\mathbf{v}^{\prime}(\mathbf{I}-\mathbf{A})^{-1}=\mathbf{v}^{\prime} \mathbf{L}
$$

where $\mathbf{p}^{\prime}$ is a row vector of prices of produced commodities by each sector and $\mathbf{v}^{\prime}$ denotes a row vector of primary inputs per one monetary unit of price; $\mathbf{I}$ is the identity matrix; $(\mathbf{I}-\mathbf{A})^{-1}$ is the Leontief inverse $\mathbf{L}$ or total requirements matrix. 
This study adopts the IO price model for estimation of changes in relative prices as a result of elimination of implicit subsidies in electricity and gas sectors. This will lead to price increases of commodities of other sectors, which require gas and electricity for production and resources from other sectors which, in turn, purchase energy as intermediate inputs. Thus, the final change of relative prices is caused by direct and indirect effects of price increases for energy. A price shock caused by phasing out subsidies in gas and electricity sectors could be recorded as a change of value-added of these sectors. Therefore, relative changes of prices for a change in primary inputs could be estimated as follows:

$$
\Delta \mathbf{p}^{\prime}=\Delta \mathbf{v}^{\prime} \mathbf{L}
$$

where $\Delta \mathbf{v}^{\prime}$ is a row vector of changes in the primary inputs and $\Delta \mathbf{p}^{\prime}$ is a vector of price changes. In other words, similar to an imposition of a tax, elimination of consumer subsidies for gas and electricity is recorded as a change of value added, $\Delta \mathbf{v}^{\prime}$, for sectors in oil and gas extraction and electricity production, respectively, to estimate resultant price changes, $\Delta \mathbf{p}^{\prime}$, and distributional effects (see Eq. (7)).

\subsubsection{Estimating CPI Changes for Different Income Groups}

The input-output price model is also used to quantify welfare impacts of energy subsidies reform utilizing data on consumption patterns of households classified per income level (from the lowest income, 1st group, to the highest, 11th group) and by area of residence, in particular, households living in rural areas and in urban areas (SSCU 2009b).

We adopt a fairly standard Laspeyres price index (see, e.g., ILO 2004), which assumes a fixed structure of goods and services, to estimate a change of the Consumer Price Index (CPI) or additional income required for purchasing the same basket of goods and services as follows:

$$
\Delta C P I_{h}=\sum_{j} \beta_{h j} \Delta p_{j}
$$

where $\triangle C P I_{h}$ refers to the change in consumer price index (in $\%$ ), $h$ indexes households with different income levels and areas of residence, and $\beta_{h j}$ is the budget share of commodity $j$ for each group of households $-h$, reported by State Statistics Committee of Ukraine (SSCU 2009b), and $\Delta p_{j}$ is a relative price change (in \%) of each sector's commodity $j$ estimated with Eq. (6). Subscript $j$ denotes the element in column of the matrix.

A time horizon is not explicitly defined in this paper. Since technological change is not foreseen in the methodology adopted and direct input coefficients remain constant, only short-term effects are studied assuming that the economy does not have time for structural adjustment and substitution between energy and nonenergy factors of production. 


\subsubsection{Partial Equilibrium Approach}

The underlying assumption of the price model is that changes in value added lead to changes in relative prices of goods and services but the quantities of goods demanded remain constant. However, economic theory suggests that in response to higher prices on normal goods, i.e., decrease in real income, rational consumers would either reduce purchases of given commodities, substitute for the cheaper ones or maintain the same level of consumption at the expense of other products. Therefore, we aim to estimate the response of final consumers to increased prices of goods and services. At the same time, industries are unable to adjust their input structure as technical coefficients are fixed in the input-output model. This is one of the most important limitations of the IO methodology, but still consistent in the short run since industries are unable to change technological processes immediately and would need more time and additional investments. Thus, we assume that all costs will be passed on to final consumers, which are more capable of responding to price shocks in the short run. Households have a number of measures available which could be relatively easily implemented to mitigate rapid increase of utilities tariffs. At the moment, residential energy consumption in Ukraine is about $250-275 \mathrm{kWh} / \mathrm{m}^{2}$ compared to $120 \mathrm{kWh} / \mathrm{m}^{2}$ in Western Europe (World Bank 2012). Moreover, $80 \%$ of buildings do not even have heat meters installed (IEA 2012). It is estimated that heat meters installation could reduce heat consumption by $15-25 \%$ decreasing heating costs by about 10-15\% (World Bank 2012). Water consumption by households is also very high in Ukraine compared to the EU countries. The main reason for this is that water supply tariffs are very low and do not even cover operational costs in the majority of the regions. In addition, tariffs are based on weighted average rather than actual consumption and most of households do not have water meters installed (see, e.g., EBRD 2011; OECD 2007).

A partial equilibrium approach is used to establish the link between price changes estimated by price model with changes in final demand derived from the classical demand driven model. The basic relationship between changes of prices and quantities of final demand could be expressed as follows:

$$
\varepsilon=\frac{\Delta Q P}{Q \Delta P}
$$

where $\varepsilon$ is the price elasticity of final demand for output, $P$ and $Q$ initial price and quantity and $\Delta P$ and $\Delta Q$ are changes of prices and quantity. A change of quantity demanded, $\Delta Q$, as a result of price changes could be estimated as follows:

$$
\Delta Q=\frac{\varepsilon Q \Delta P}{P}
$$

notation (9) in matrix algebra is expressed as

$$
\Delta \mathbf{y}=-\Delta \hat{\mathbf{p}} \hat{\varepsilon} \mathbf{y}_{0}
$$

where $\mathbf{y}_{0}$ is the initial vector of final demand, $\Delta \mathbf{y}$, column vector of change in final demand, $\Delta \hat{\mathbf{p}}$ diagonal matrix (a matrix with the elements of the vector in the main 
Table 1 Price elasticities of demand for output

\begin{tabular}{ll}
\hline Economic sectors & Price elasticities \\
\hline Forestry & -0.5 \\
Agriculture and Fishing & -0.2 \\
Coal mining & -0.2 \\
Oil and gas extraction & -0.2 \\
Mining of non-energy materials & -0.2 \\
Food & -0.2 \\
Textiles & -0.7 \\
Pulp and paper & -0.7 \\
Manufacture of coke and petroleum & -0.7 \\
Chemicals and plastics & -0.7 \\
Manufacture of other non-metallic products & -0.7 \\
Metallurgy & -0.7 \\
Machinery & -0.7 \\
Other manufacture & -0.7 \\
Electricity production & -0.2 \\
Gas manufacture & -0.2 \\
Hot water supply & -0.2 \\
Water purification and distribution & -0.2 \\
Construction & -0.7 \\
Trade and repair & -0.7 \\
Hotels and restaurants & -1.0 \\
Transport & -0.7 \\
Finance & -0.8 \\
Business services & -0.8 \\
Public administration & -0.5 \\
Education & -0.5 \\
Health care & -0.5 \\
Other & -0.5 \\
\hline & \\
\hline & \\
\hline
\end{tabular}

diagonal and zeros in outside the main diagonal) of price changes (in $\%$ or share of unity) and $\hat{\varepsilon}$ diagonal matrix of elasticities. In other words, we diagonalize the vector of price changes $\Delta \mathbf{p}^{\prime}$ (obtained with Eq. (6)) to receive a diagonal matrix $\Delta \hat{\mathbf{p}}$ and use $\mathbf{y}_{0}$, initial vector of final demand recorded in the IO table, and $\hat{\varepsilon}$ diagonal matrix of elasticities (see Table 1) to estimate a change in final demand, $\Delta \mathbf{y}$, which is then used in subsequent steps of the analysis.

Unfortunately, consistent estimates of price elasticities for most commodities are often not available. There are numerous studies on price sensitivity of energy consumption showing energy consumption likely to be relatively inelastic in the shortrun since few substitution options are available for households (e.g., Cohn 1980; Prosser 1985; Bentzen and Engsted 1993; Bernstein and Griffin 2006). Atakhanova and Howie (2007) estimated short and long-run price-elasticity of residential electricity consumption as of -0.22 and -1.10 . Nahata et al. (2007) obtained comparable re- 
sults for urban and rural households in Russia. Some research has been carried out on demand sensitivity of agricultural commodities and food products to price changes, which are also likely to be inelastic in the short-term (e.g., Andrikopoulos et al. 1987; Russo et al. 2008) and transportation services (Wohlgemuth 1997). However, it is especially difficult to find elasticities for certain industries, especially, for effects in the short-run. Considering limited availability of real estimates of price sensitivity for all economic sectors, Ho et al. (2008) derived elasticities from a macroeconomic model for the US under constrained conditions; Choi et al. (2010) adopted assumptions on several scenarios for price elasticities. This study assumes that similar sectors would have similar price elasticities (see Table 1). This assumption was made due to limited evidence from the literature (e.g., Atakhanova and Howie 2007; Ho et al. 2008; Nahata 2007; Russo 2008; Wohlgemuth 1997).

\subsubsection{Input-Output Demand-Driven Model}

At the next stage of analysis, the classical Leontief (see, e.g., Miller and Blair 2009) IO model is utilized to estimate demand-induced changes of the total output and associated changes of employment, total energy, and gas consumption and GHG emissions.

A change of total output $\Delta \mathbf{x}$ as a result of change in final demand $\Delta \mathbf{y}$ (calculated with Eq. (10)) is estimated as

$$
\Delta \mathbf{x}=(\mathbf{I}-\mathbf{A})^{-1} \Delta \mathbf{y}=\mathbf{L} \Delta \mathbf{y}
$$

A decrease in gross outputs would result in decline in resource consumption, emissions or other factors. The IO model is extended to examine these effects as well. Similar to the coefficients in the A matrix, physical coefficients $b_{i}$ are calculated by dividing emissions $e_{i}$ of each sector by respective sectoral output $x_{i}$ as

$$
b_{i}=\frac{e_{i}}{x_{i}}
$$

Subscript $i$ denotes the element in row of the matrix. From (12), a change in output $\Delta x$ (estimated with Eq. (11)) would result in a change of environmental and socioeconomic factors and could be calculated as

$$
\Delta \mathbf{e}=\hat{\mathbf{b}} \Delta \mathbf{x}
$$

where $\Delta \mathbf{e}$ is a vector of change in resource inputs or emissions, $\hat{\mathbf{b}}$ is the diagonal matrix of physical coefficients.

\subsection{Data}

The most recent input-output table for Ukraine, available for 2008 is used in this study (SSCU 2010). In the columns of the table, industry sectors are classified according to Ukrainian statistical classification of economic activities, which was developed based on classification of economic activities in the European Community (NACE). Classification of commodities and services (in rows of the table) is in line 
Table 2 Schematic representation of the IO table

\begin{tabular}{llllll}
\hline & $\begin{array}{l}\text { Buying sectors } \\
1 \cdots j \cdots n\end{array}$ & $\begin{array}{l}\text { Final } \\
\text { demand }\end{array}$ & $\begin{array}{l}\text { Total } \\
\text { output }\end{array}$ & $\begin{array}{l}\text { Environmental and } \\
\text { socioeconomic factors }\end{array}$ \\
\hline Selling sectors & 1 & Interindustry transactions $\mathbf{Z}$ & $\mathbf{y}$ & $\mathbf{x}$ & $\mathbf{E}^{\prime}$ \\
& $\vdots$ & & & \\
& $\vdots$ & & & \\
Value added $\mathbf{v}^{\prime}$ & $n$ & & & \\
Total outlays $\mathbf{x}^{\prime}$ & & & & \\
\hline
\end{tabular}

with state classification of commodities and services based on European Classification of Products by Activity (CPA).

The table consists of 38 sectors, 6 of which refer to energy goods and services, 11 manufacturing industries and construction, 16 service sectors, 2 transport sectors and communications, 3 sectors capture activities in agriculture, fishing and forestry. Table 2 illustrates interindustry transactions between sectors $(\mathbf{Z})$, final demand for each industry's outputs $(\mathbf{x})$ is reflected in the column vector $\mathbf{y}$ and $\mathbf{v}^{\prime}$ refers to primary inputs required by each sector. Value added part of the table incorporates wages for employees, profits, taxes, and subsidies on production. In addition to final deliveries to households, government and nonprofit institutions, the "use" section of the table provides data on gross capital formation and net exports.

The table is augmented by additional columns in physical units to account for effects on GHG emissions, employment, total energy and gas consumption by each sector utilizing the data published by the State Statistics Committee of Ukraine (2009a, 2009b, 2009c) and GHG emissions inventory of Ukraine (MENR 2010). Since the level of detail for each examined variable is different, the table has been aggregated to complement the data on environmental and socioeconomic factors. In particular, the table was aggregated to 13 economic sectors to complement GHG emissions data available and to 28 sectors to study effects on energy consumption and employment.

\subsection{Limitations}

It is important to note that obtained results should be treated with caution because of the data caveats associated with this study and inherent limitations of the methods used. First of all, the accuracy of obtained results depends on the quality of the data used in the model. National income accounts always have a "residual error," which is the difference of GDP estimates according to two of three possible conventions (Perman et al. 2003). Secondly, input-output models embody a number of simplifying assumptions, which should be considered carefully while interpreting obtained results. However, those assumptions are transparent and mathematically traceable. One of the most important shortcomings of the input-output analytical framework is that technical coefficients and the coefficients of physical factors, e.g., GHG emissions 
and energy inputs do not change as a result of energy subsidy induced price changes. In other words, there are no substitution responses to increased prices of energy inputs. At the same time, price elasticities of demand are incorporated in the study design to allow for adjustment of quantities of goods consumed to price changes. Ho et al. (2008) argue that this approach could be intrinsically inconsistent since the response of final consumers to higher prices is taken into an account while producers are not able to switch to less energy intensive inputs. Therefore, an assumption is made that all additional costs to producers are passed on to final consumers. In addition, Perman et al. (2003) note that, in reality, higher energy prices would result in consumption of less energy per unit of output and less energy-intensive intermediate inputs, which in turn would decrease prices. Thus, the input-output price model sets up the upper margins to price changes which would eventually occur. Moreover, there are some other important limitations of using input-output analysis. In particular, price changes would also affect investment decisions and labor inputs, which are not taken into account (Ho et al. 2008). Nevertheless, assumptions of the approach are consistent with the short-term time framework adopted in the analysis. In other words, the impacts of subsidy reform are estimated before the economy has adjusted for price changes assuming that there is no time for structural changes and substitution of labor and capital for energy as well as cross-substitution of fuels. Technological change and cross-substitution between energy and nonenergy factors of production could be explicitly modeled with (CGE) models, which on the other hand introduce other model-immanent problems (see, e.g., Clarete and Roumasset 1986; Scrieciu 2007). Other methodological limitations are highlighted in the analysis section since they are important for interpretation of estimates obtained.

\section{Results and Discussion}

\subsection{Energy Subsidies in the Gas and Electricity Sectors of Ukraine}

We evaluated consumer subsidies for gas and electricity sectors utilizing the price gap approach, which is described in detail in the Methodology section. Estimated reference prices that would prevail in an "ideal" market (where all subsidies are eliminated) are significantly higher than current prices for gas and electricity (see Table 3).

Retail gas prices for households and district heating companies constitute only $26 \%$ and $57 \%$ of the reference price, respectively. In comparison, current prices for industry and state-funded institutions are equal to $81 \%$ of the reference price because tariffs for these consumer groups are based on the import gas price. It is important to note that the estimate is highly sensitive to the import border price. The price of Russian gas for Ukraine is indexed to prices of oil products at the global market and also depends on the political situation between two countries. Hence, it is likely that the gas price will continue to grow in the future and domestic gas tariffs should be increased in line with import gas prices to prevent price distortions in the domestic market.

Electricity prices for all consumer groups are significantly lower than the reference price. Tariffs should be increased by about two times the current level for nonresidential consumers and almost three times for households in order to reflect long-run 
Table 3 Comparison of actual (average for 2008) and reference prices for gas and electricity

\begin{tabular}{|c|c|c|c|c|}
\hline \multirow[t]{2}{*}{ Consumer group } & \multicolumn{2}{|c|}{$\begin{array}{l}\text { Gas sector }^{\mathrm{a}} \\
\left(\mathrm{UAH} \text { per } 1000 \mathrm{~m}^{3}\right)\end{array}$} & \multicolumn{2}{|l|}{$\begin{array}{l}\text { Electricity sector }{ }^{\mathrm{a}} \\
\text { (UAH/MWh) }\end{array}$} \\
\hline & $\begin{array}{l}\text { Average end-user } \\
\text { prices }\end{array}$ & Reference price & $\begin{array}{l}\text { Average end-user } \\
\text { prices }\end{array}$ & Reference price \\
\hline Households & 372.7 & 1431.6 & 243.6 & 615.7 \\
\hline State-funded institutions & 1165.1 & & - & \\
\hline District heating companies & 826.4 & & 332.9 & \\
\hline Industry & 1165.1 & & 332.9 & \\
\hline
\end{tabular}

Source: own estimates

${ }^{\mathrm{a}} 1 \mathrm{UAH}=0.19$ USD, average in 2008 (National Bank of Ukraine 2011)

production cost. Interestingly, the estimated reference price is still lower than the electricity tariffs for households in most EU countries. In particular, the reference price of 615.7 UAH/MWh equals 0.064 EUR/kWh. In comparison, the lowest electricity tariff for households (at annual consumption $3500 \mathrm{kWh}$ ) was in Latvia, 0.068 EUR/kWh, and the highest in Italy, 0.268 EUR/kWh as of July, 2010 (Europe's Energy Portal 2010).

Following the price-gap approach described in the Methodology section (see Eqs. (1)-(4)), we found that implicit subsidies at 2008-consumption levels amounted to almost 26 billion UAH ( 5 billion USD) in the gas sector and approximately 24 billion UAH (4.6 billion USD) in the electricity sector. It should be noted that estimates obtained represent a lower margin for subsidies in the sector since underpriced fuel inputs such as gas and coal are not taken into an account. Interestingly, IEA (2011b) estimates of subsidies differ significantly ( 8.27 billion USD and 1.51 billion USD for gas and electricity sector, respectively). Although the study adopted the IEA methodology (1999, 2006a, 2006b, 2008), obtained results are not directly comparable with estimates provided in the Fossil fuel subsidy database (IEA 2011b) because it is not clear what assumptions have been used for estimation of the reference prices.

End-user subsidies in gas and electricity sectors are equal to $2.7 \%$ and $2.6 \%$ of the GDP, respectively, and cumulatively comparable to approximately $16 \%$ of the state budget. ${ }^{3}$ However, it is essential to point out that these estimates do not reflect direct state transfers to the energy sector and only capture market interventions resulted in decreased prices for final consumers. In comparison, direct financial support to oil and gas extraction sector and electricity production recorded in the IO table roughly equals 2.2 billion UAH ( 0.4 billion USD) and 1.3 billion UAH ( 0.3 billion USD), respectively (SSCU 2010).

\subsection{Effects on Relative Prices, Production and Employment}

This study explores effects of rapid price rises for gas and electricity as a result of a hypothetical elimination of implicit subsidies in these sectors. In fact, this would

\footnotetext{
${ }^{3}$ In 2008, GDP was at the level of 949864 million UAH (180336 million USD) and budget expenditure was 312018 million UAH (59238 million USD) (SSCU 2009a).
} 


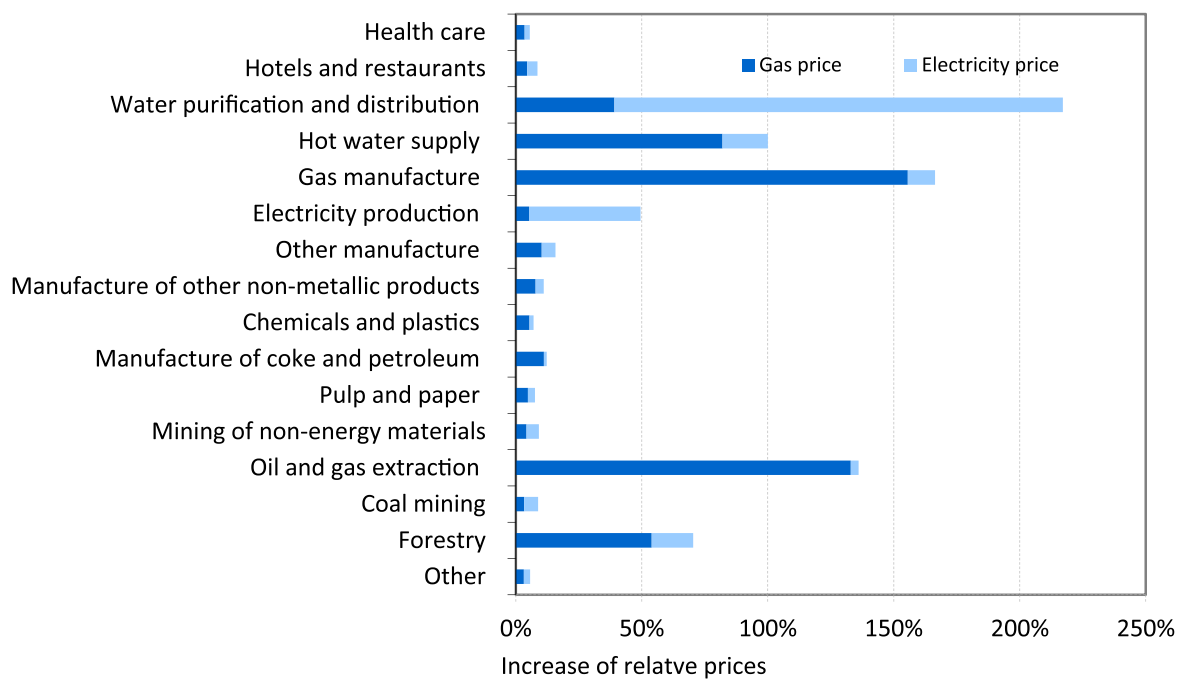

Fig. 1 Increase of relative prices for different economic sectors

lead to a fourfold increase of the gas price for households to reflect true opportunity cost of domestically produced gas and an increase of the electricity price of around three times to ensure compensation for long-run production costs. It is important to note, however, that these scenarios are hypothetical and the government is advised to increase prices gradually to mitigate negative economic and social effects. Unlike the IER (2006, 2007) studies, this paper investigates short-term effects of price shocks assuming that economy does not have enough time to allow for restructuring and substitution between energy and nonenergy factors of production. It is estimated that price increases for gas and electricity of $1.43 \mathrm{UAH}$ per $\mathrm{m}^{3}\left(0.27\right.$ USD per $\left.\mathrm{m}^{3}\right)$ and $0.62 \mathrm{UAH} / \mathrm{kWh}(0.12 \mathrm{USD} / \mathrm{kWh})$ would more than double relative prices for some industries while prices of others are not considerably affected. Interestingly, prices in oil and gas extraction and electricity production sectors have increased less than in some other industries. Figure 1 illustrates the increase in relative prices for most affected sectors (see Additional file 1, Table A.1 for breakdown of price changes for all sectors). A group of sectors in supply and distribution of gas, electricity, and water are likely to experience the highest increase of relative prices. This could be explained by large input requirements for gas and electricity per unit of output. Assuming that all price shocks are passed on to final consumers, relative prices of services of the water purification and distribution, for example, would rise by about $40 \%$ and about $180 \%$, respectively, as a result of price hikes in gas and electricity sectors. Other highly impacted sectors are forestry, mining of nonenergy materials and several manufacturing sectors, particularly the manufacture of coke products and manufacture of other nonmetallic mineral products.

Steep price increases for commodities of different sectors are likely to enforce knock-on effects on final demand for these products since consumers would seek to minimize their losses by introducing energy saving measures or switching to less energy-intensive goods. However, demand sensitivity is likely to be inelastic in the 


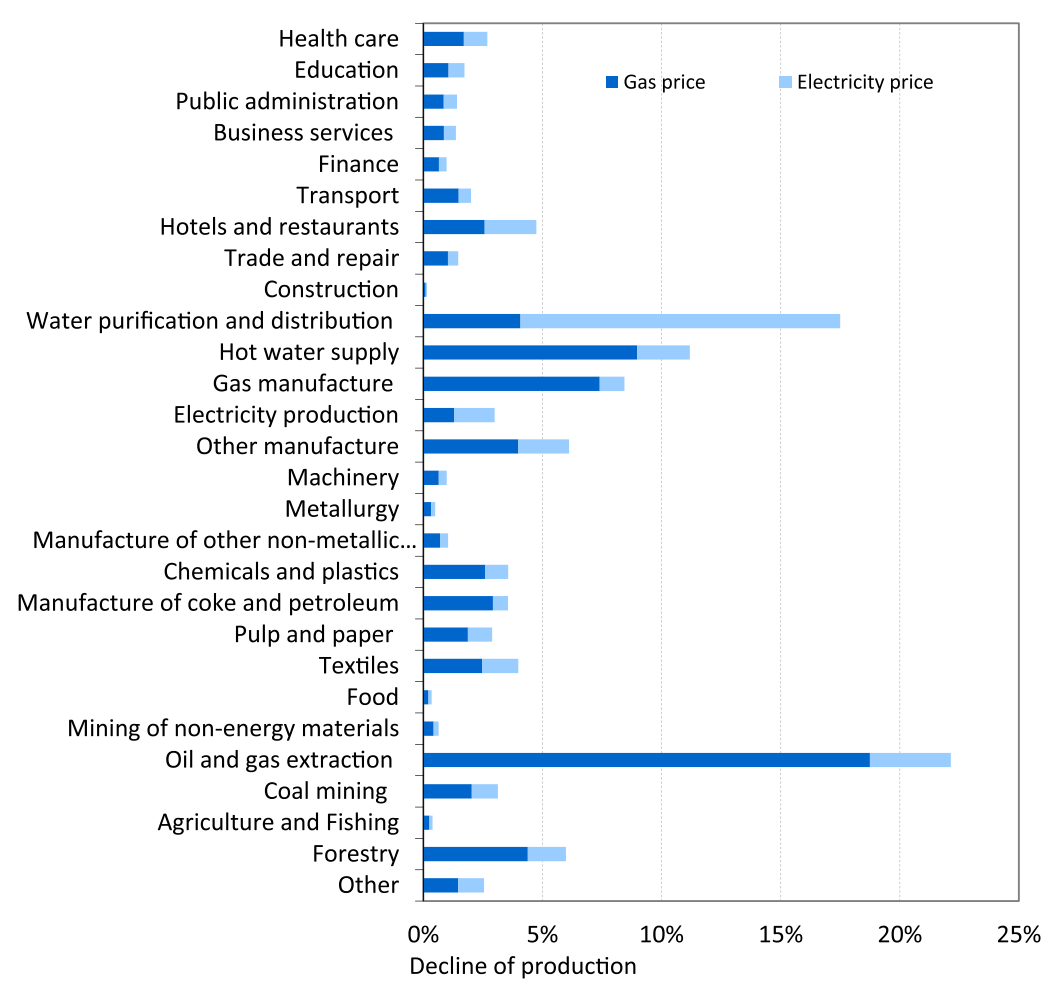

Fig. 2 Decline of production for different economic sectors

short-term for most sectors. We found that examined price shocks could cumulatively result in reduction of total final demand by about $2.5 \%$ or around 18.7 billion UAH (3.6 billion USD) (see Additional file 1, Table A.1 for results for all sectors). Assuming that investment and net exports do not change in the short-run a phasing out subsidies in the gas and electricity sectors could result in a decline of GDP by about $1.35 \%$ and $0.62 \%$, respectively, relative to 2008 level. It should be noted that higher energy prices could bring higher revenues to the government in the form of tax payments. However, this effect may be counteracted by reduced consumption and production; in case the former effect will prevail and government revenue will still increase. For simplicity, this analysis assumes that the excess money will be spent to reduce foreign debt of Ukraine rather than a recycling back of revenues to consumers.

A drop in final demand would in turn lead to decline of production of energyintensive sectors in the first place and would also have indirect effects on other industries. Utilizing the demand-driven IO model, we estimate that total output would decrease by about $1.8 \%$ or 43 billion UAH. Figure 2 illustrates the breakdown of the percentage decline in gross output for all sectors.

A decline of total production would lead to excess of labor per unit of output. Thus, producers would have to fire extra workers to minimize losses. It is estimated that the number of jobs would be reduced by 223 thousand or by $1.3 \%$ and $0.7 \%$ as a result of the removal of subsidies in gas and electricity sectors, respectively. Employment 
effects for each sector are determined by labor intensity and percentage decline in gross output. For example, service sectors (e.g., public administration, education, and health care) are the most labor-intensive sectors with up to 27 employees per million UAH of output in health care. However, a relatively low decline in total output would result in only 1-2 \% decline in the number of jobs. In comparison, relatively low labor intensity in oil and gas extraction (about 4 workers per unit of output) coupled with a major decline in production, illustrated in Fig. 2, would result in a $22 \%$ loss of jobs. Sectors in production and distribution of water and gas would be also highly affected due to large cuts in production.

Overall, an energy subsidy reform is likely to have negative effects on the total employment in the short-run. However, it is important to note that these estimates are the indication of the upper bound of employment effects considering uncertainty on adjustment of the production levels. Nevertheless, over a longer time horizon, the economy would restructure toward less energy-intensive sectors and reduced employment in the shrinking sectors is likely to be compensated by expanded production and new jobs in other industries. However, labor reallocation could not be modeled within the chosen IO framework.

\subsection{Income Effects for Different Income Groups}

We examine income distribution effects for households resulting from energy pricing policy reform in the gas and electricity sectors. The consumer price index reflects the cost of a standard basket of goods and services required by households for an everyday life, and hence, could be an appropriate measure for estimation of welfare effects of energy pricing policies. The overall effect is determined by the increase of relative prices for different economic sectors and structure of consumer expenditure for different income groups. Figure 3 illustrates increase of CPI or percentage of additional income required by rural and urban households for buying the same set of goods and services. Adjusting gas and electricity prices to market levels will reduce the real income and purchasing power by about $13.2 \%$ for urban poor and by $11.5 \%$ for higher income households. Rural families are comparatively less susceptible to an energy subsidy reform since utilities and housing related payments, which face the highest price increase, constitute a lower share of their monthly expenditures. In particular, urban families allocate between $7.7 \%$ and $10.8 \%$ of their budgets to utility payments while rural ones only allocate 4.2-6.4\% (SSCU 2009b).

It can be noted from Fig. 3 that an energy subsidy reform is likely to be regressive for urban but nonregressive for rural households. Interestingly, regressive effects are concealed if urban and rural households are aggregated (see Fig. 4). Both urban and rural families are more vulnerable to elimination of gas subsidies with Consumer Price Index (CPI) rising by $7.7 \%$ for urban poor and by $6.4 \%$ for higher income urban families. For rural households, these figures are $5.4 \%$ and $4.6 \%$, respectively.

Figure 4 shows contribution of aggregate consumption categories to overall change of CPI for different income groups (rural and urban households are aggregated). Housing is largely responsible for the energy prices induced increase in the inflation rate. It constitutes $76 \%$ for the lowest and $70 \%$ for the highest income households in the cumulative CPI. Food and clothing, which also reflect basic necessities, follow a similar pattern with their CPI fractions being higher for the poor 


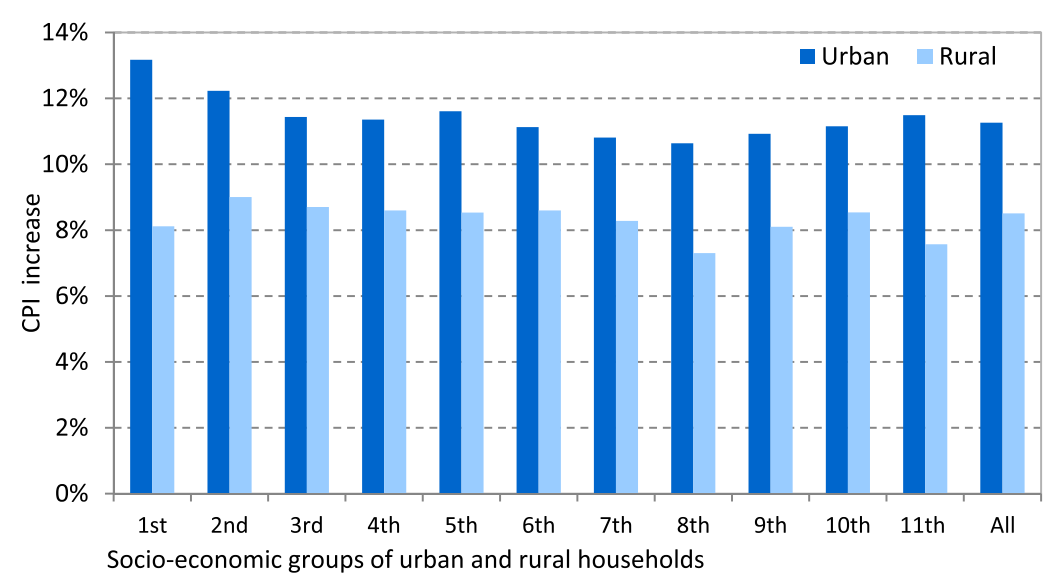

Fig. 3 CPI increase for different socioeconomic groups of urban and rural households. Note: socioeconomic groups are ordered from lowest (1st) to highest income (11th)

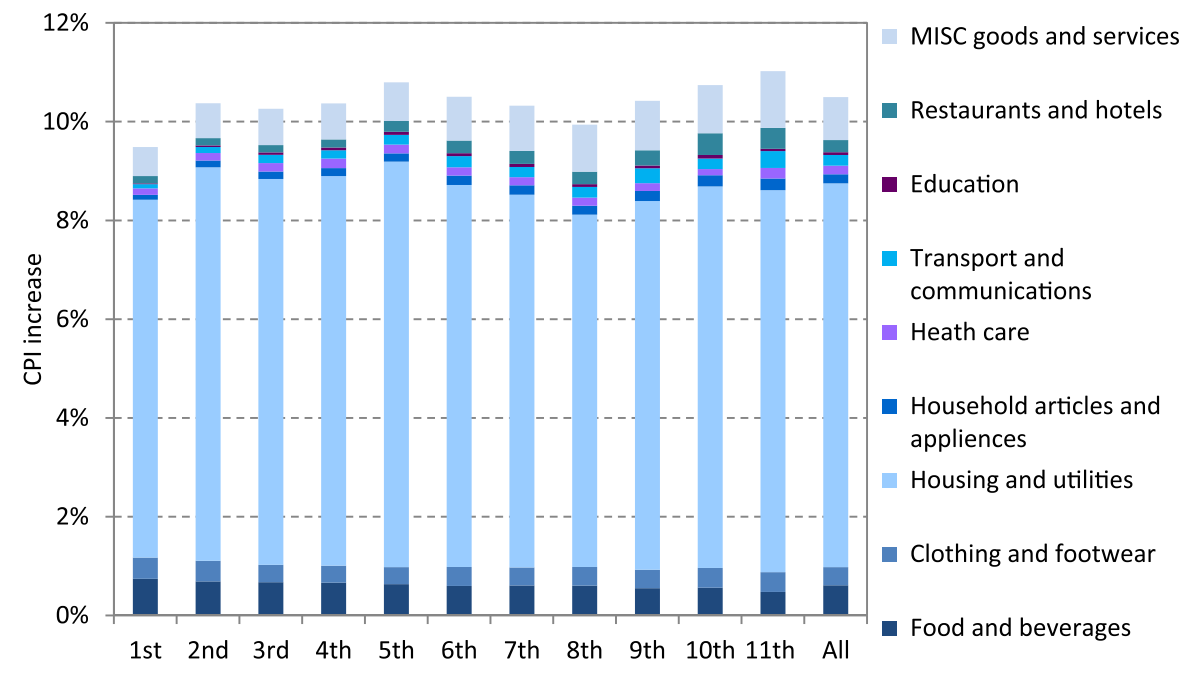

Socio-economic groups of households

Fig. 4 Increase of CPI differentiated between 9 aggregate consumption categories by socioeconomic groups. Note: (1) socioeconomic groups are ordered from lowest (1st) to highest (11th). (2) See Additional file 2, Table B.1. for compatibility of IO sectors with aggregate consumption categories

families and lower for higher income families. Other consumption categories, especially more luxury goods such as miscellaneous goods and restaurants and hotels depict quite an opposite situation with CPI shares being lower for poor households and higher for the ones with higher income.

It is important to note that estimated inflation rates represent the upper bounds of CPI changes because consumption patterns of households would change by shifting to comparable commodities for which prices had increased to a lesser extent, which 
in turn would reduce the CPI impact of eliminating subsidies. However, the IO model incorporates the assumption that household consumption patterns do not change in response to changes of relative prices of goods and services similar to constant technical coefficients (Perman et al. 2003), which is a reasonable assumption for short-time horizons explored in this study.

It is interesting to compare an average estimated CPI for all households of $10.5 \%$ (see Fig. 4) resulting from a hypothetical energy subsidies reform with the actual inflation rate at the same time, which amounted to $12.8 \%$ and $25.2 \%$ in 2007 and 2008, respectively (SSCU 2009a). Therefore, it should be noted that immediate removal of energy subsidies and liberalization of energy prices at one step would not be tolerable to society considering already relatively high annual inflation rates observed in Ukraine. Hence, an increase of energy prices up to market levels should be implemented in steps and accompanied by social support programs targeting the most vulnerable households.

\subsection{Effects on Energy Consumption}

Elimination of energy subsidies in electricity and gas sectors is essential to decrease the energy-intensity of the economy of Ukraine, which is presently much higher than in developed counties (IEA 2011a). This could be explained by a number of reasons including outdated technologies used in production processes and energy conversion (IEA 2006b); however, cheap energy is one of the most important if not the primary determinant. A report by IEA (1999) presents evidence that there is a strong negative correlation between electricity prices and energy consumption per unit of GDP across 27 OECD and 22 non-OECD countries. Although other external drivers such as climate conditions, average distances, or population density might also come into play, such a strong inverse relationship between electricity use and prices could not be fully explained by structural parameters.

We found that a removal of the indirect gas and electricity subsidies would lead to a drop in total energy consumption by about $2.5 \%$ (5 million tons of coal equivalent ${ }^{4}$ ) in the short term (see Eq. (13) in Sect. 3), $68 \%$ of this reduction was due to phasing out subsidies in the gas sector (see Additional file 1, Table A.3 for a breakdown of results for all sectors). Figure 5 shows the sectors that could generate the highest energy savings. In particular, the manufacture of coke and petroleum products could reduce energy consumption by more than 1 million tons of coal equivalent due to relatively high energy requirements per unit of output and a considerable decline in total production of the sector (see Fig. 5). However, in relative terms, this would mean only a $6 \%$ decline in overall energy consumption of the sector. Significant amounts of energy could also be saved in the supply and distribution of gas, electricity, and water, which have the highest average energy-intensity of about 0.5 thousand tons of coal equivalent, followed by metallurgy, chemicals, and transportation.

It is important to note that obtained results are of indicative character and depend highly upon responsiveness of consumers to price changes and flexibility in

\footnotetext{
${ }^{4}$ Coal equivalent instead of oil equivalent is usually used in Ukraine. Coal equivalent could be converted to oil equivalent by multiplying the former by 0.7 .
} 


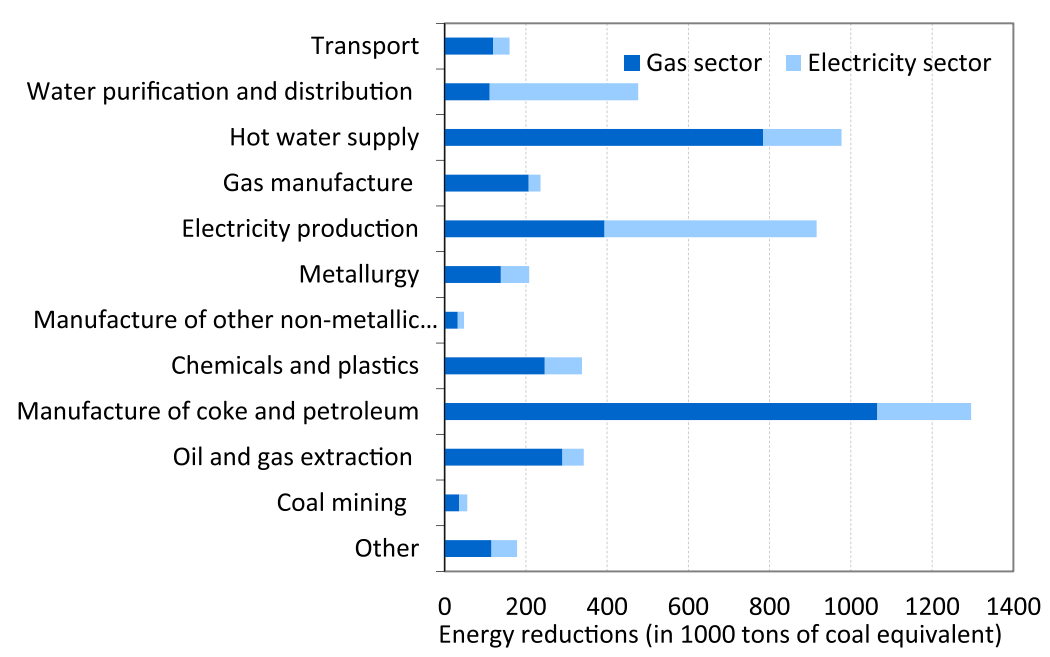

Fig. 5 Energy saved (in 1000 tons of coal equivalent) as a result of elimination of subsidies in gas and electricity sectors

production adjustments of economic sectors. Moreover, it should be noted that energy savings are caused by demand-induced decline in total production and not because of technological change since significant efficiency improvements are not feasible in the short-term and, therefore, ignored in this analysis (see the Sect. 3.2.3 for more detail). Over the longer-term, however, price signals could stimulate energy efficiency improvements and development of less energy-intensive industries.

Since energy security is of big concern for Ukraine as a net-importer of gas (domestic production could satisfy only about $20 \%$ of the demand (IEA 2006b)), it is also of interest to examine short-term effects of the subsidy reform on total gas consumption. Figure 6 illustrates sectors that could bring the highest decline in gas use (see Additional file 1, Table A.3 for a breakdown of results for all sectors). Sectors in hot water supply and electricity production are likely to contribute $21 \%$ and $19 \%$ of the total decline in gas consumption, respectively. Chemicals and plastics would also reduce gas use considerably due to high requirement for gas inputs in production.

Overall, elimination of subsidies in the gas and electricity sectors would bring reductions of about $3.6 \%$ in total gas consumption which equals roughly 1.6 billion $\mathrm{m}^{3}$. However, considering the long-term nature of interstate gas contracts, it is not likely that Ukraine could reduce gas imports in the short-term. Obtained figures rather serve as an indication of potential gas savings if energy pricing policy is improved and final consumers are required to pay the real cost of gas and electricity. Although in the short-term gas use would decline solely because of drop in final demand and GDP, price stimuli are essential to trigger energy efficiency improvements, which could bring even larger savings in the future without adverse impacts on the GDP growth. For example, Flanagan et al. (2007) utilize a semistructural approach to examine the role of efficiency in mitigating negative impacts of energy price shocks. Assuming $3 \%$ of GDP for intermediate energy consumption, the authors have estimated that 


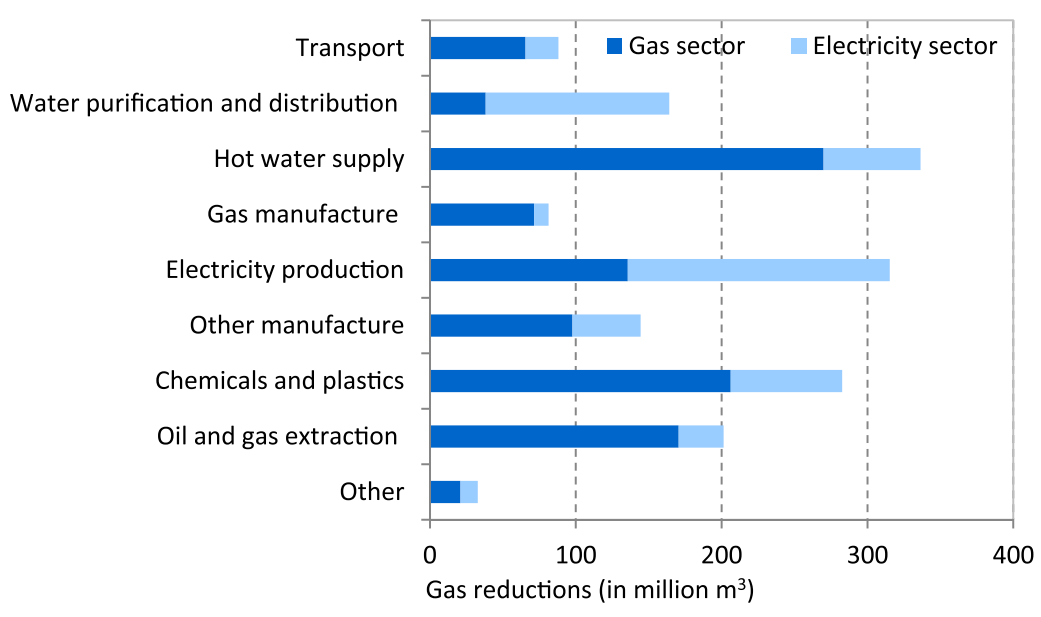

Fig. 6 Reduction in gas consumption in different economic sectors

negative impacts of a $10 \%$ increase of the import gas price could be completely offset by $9 \%$ improvement in gas efficiency.

\subsection{Effects on GHG Emissions}

We estimate that elimination of energy subsidies in gas and electricity sectors would result in a reduction of about 15 million tons of $\mathrm{CO}_{2}$-eq. or a $3.6 \%$ reduction of total GHG emissions of Ukraine. Figure 7 illustrates each sector's share in total GHG emissions reductions (see also Additional file 1, Table A.4 for a breakdown of results for all sectors). Although estimated energy subsidies are of similar magnitude in both sectors, removal of subsidies in the gas sector has a significantly larger effect on emissions reductions.

This could be explained by the fact that estimated subsidies are much higher than the present value added of the gas sector of about 7 billion UAH (1.3 billion USD) compared to value added of the electricity sector of about 23 billion UAH ( 4.4 billion USD). Hence, elimination of subsidies would result in higher prices for gas, which in turn would have a larger effect on relative prices, final demand, and output of other sectors. The largest share of emissions reductions would be observed in the oil and gas extraction sectors due to a decline of fugitive methane emissions. Energy supply and distribution sectors are also likely to deliver considerable emission cuts with reductions in electricity production and hot water supply of about $10 \%$ and $16 \%$, respectively. GHG emissions from fuel combustion by households would be $15 \%$ lower.

It is important to note that cross-substitution between different fuels is not considered in this paper. It is a major limitation for evaluation of impacts on GHG emissions since higher prices for one type of fuel could stimulate end-users to substitute for cheaper ones in the long run. Subsidies for coal are beyond the scope of this paper; however, coal is the most carbon-intensive fuel. If end-user subsidies are eliminated only in gas and electricity sectors and coal prices remain at below market levels (due 


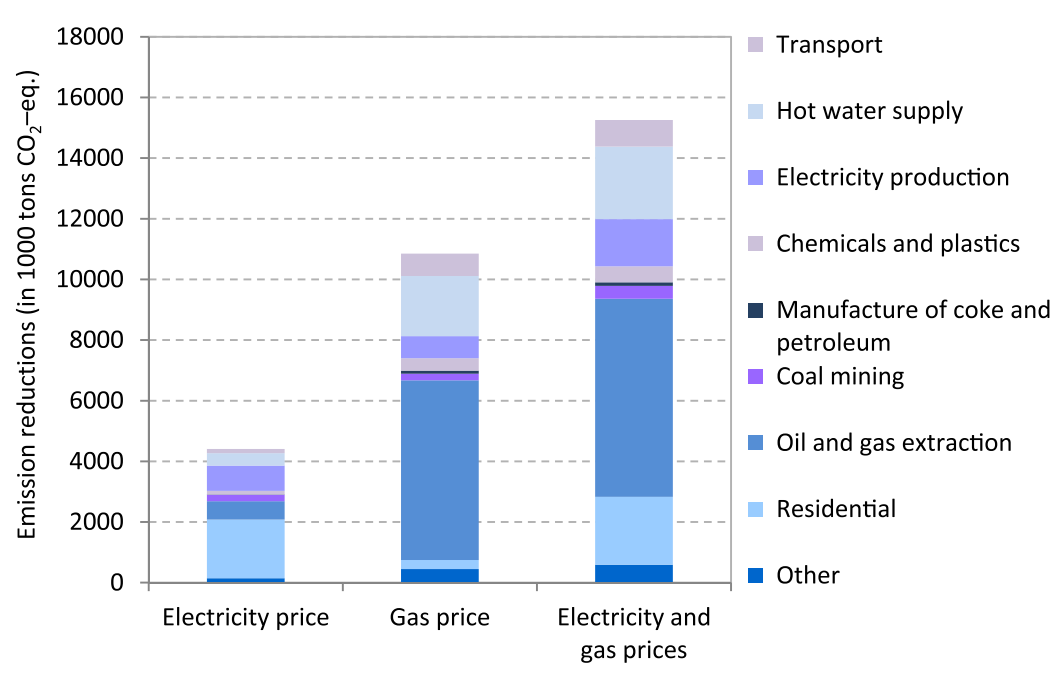

Fig. 7 Emission reductions (in 1000 tons $\mathrm{CO}_{2}$-eq.) in each sector as a result of elimination of gas and electricity subsidies

to producer subsidies), both end-users and intermediate consumers, e.g., power plants are likely to switch to coal as less expensive energy source as much as technological capacity would allow. In this case, liberalization of gas and electricity prices would likely result in larger coal use and higher GHG emissions. Hence, energy subsidy reform should consider all fuels to prevent undesirable effects. Moreover, depending on the resultant market price of different fuels an additional measure might be required to prevent substitution for coal, e.g., carbon tax charged depending on the carbon-intensity of the output.

\section{Conclusions}

This paper has adopted the price-gap approach for estimation of indirect end-user subsidies in gas and electricity sectors in Ukraine and considered a hypothetical elimination of energy subsidies. Although a minor decline in GDP is expected, this is the short-term price to be paid to correct market distortions that had been accumulated over decades of inefficient energy pricing. Other benefits of the removal of subsidies would include a reduction in total energy consumption and GHG emissions, which would drop by about $2.5 \%$ and $3.6 \%$, respectively. In addition, these shortterm demand-induced effects would potentially trigger dynamic effects of accelerated technological improvements over the long term.

Energy subsidy reform is likely to have negative employment effects due to steep production cuts in resource-intensive sectors. However, a short-term loss of jobs could be minimized if the government would create favorable conditions for the establishment of new working places in other sectors. Removal of subsidies is also likely to be regressive with lower income groups, who spend a larger share of their 
income on fuels, to be affected more than richer households. However, this effect could be mitigated by social policies targeting the most vulnerable.

It is important to note that complete and immediate elimination of subsidies is considered here as a theoretical exercise and is done to provide an estimate of potential losses and negative social effects. A gradual phase-out is more advisable to mitigate negative effects. In addition, end-user subsidies reform in gas and electricity sectors is not sufficient to correct all price distortions. Producer subsidies in the coal sector should be also eliminated to stimulate technological change toward a less carbonintensive economy and to avoid switching to cheaper coal. Moreover, obtained results are of an indicative character due to data caveats and other shortcomings of the methods applied, and only illustrate the magnitude of the likely effects of subsidy reform in the short-run. Nevertheless, even rough quantitative estimates could be useful for decision-makers since they provide valuable insights for the planning of energy and climate policy of Ukraine.

\section{Competing Interests}

The authors declare that they have no competing interests.

\section{References}

Andrikopoulos AA, Brox JA, Georgakopoulos TA (1987) Short-run expenditure and price elasticities for agricultural commodities: the case of Greece, 1951-1983. Eur Rev Agric Econ 14:335-346

Atakanova Z, Howie P (2007) Electricity demand in Kazakhstan. Energy Policy 35:3729-3743

Bentzen J, Engsted T (1993) Short- and long-run elasticities in energy demand: a cointegration approach. Energy Econ 15:9-16

Bernstein MA, Griffin J (2006) Regional differences in the price-elasticity of demand for energy. National Renewable Energy Laboratory. Available via DIALOG. http://www.nrel.gov/docs/fy06osti/ 39512.pdf. Accessed 25 Aug 2012

Bohi DR (1991) On the macroeconomic effects of energy price shocks. Resour Energy 13:145-162

Burniaux J-M, Martin JP, Olivera-Martins J (1992) The effect of existing distortions in energy markets on the costs of policies to reduce $\mathrm{CO}_{2}$ emissions: evidence from GREEN. Available via DIALOG. http://www.oecd.org/eco/productivityandlongtermgrowth/35044850.pdf. Accessed 25 Aug 2012

Burniaux J-M, Chateau J, Dellink R, Duval R, Jamet S (2009) The economics of climate change mitigation: how to build the necessary global action in a cost-effective manner? Available via DIALOG. http://www.oecd.org/officialdocuments/displaydocumentpdf?cote=ECO/WKP\%282009\%2942\& doclanguage=en. Accessed 25 Aug 2012

Choi J, Bakshi BR, Haab T (2010) Effects of a carbon price in the U.S. on economic sectors, resource use, and emissions: an input-output approach. Energy Policy 38:3527-3536

Cohn SM (1980) Fuel choice and aggregate energy demand in the residential and commercial sectors. Energy 5:1203-1212

Clarete RL, Roumasset JA (1986) CGE models and development policy analysis: problems, pitfalls, and challenges. Am J Agric Econ 68: 1212-1216

Corden M (1957) The calculation of the cost of protection. Econ Rec 33:29-51

Dodonov B, Opitz P, Pfaffenberger W (2004) How much do electricity tariff increases in Ukraine hurt the poor? Energy Policy 32:855-863

EBRD (2011) Residential sector of Ukraine: legal, regulatory, institutional, technical and financial considerations. Available via DIALOG. http://www.teplydim.com.ua/static/storage/files/files/ Market_Assessment_Report_Final_Eng_Sep-2011.pdf. Accessed 21 Aug 2013

Ellis J (2010) The effects of fossil-fuel subsidy reform: a review of modeling and empirical studies. Global Subsidies Initiative. Available via DIALOG. http://www.globalsubsidies.org/files/assets/ effects_ffs.pdf. Accessed 25 Aug 2012 
Europe's Energy Portal (2010) Domestic electricity and gas prices. http://www.energy.eu. Accessed 30 July 2010

Fankhauser S, Tepic S (2007) Can poor consumers pay for energy and water? An affordability analysis for transition countries. Energy Policy 35:1038-1049

Fankhauser S, Rodionova Y, Falcetti E (2008) Utility payments in Ukraine: affordability, subsidies and arrears. Energy Policy 36:4168-4177

Feng K, Hubacek K, Guan D, Contestabile M, Minx J, Barrett J (2010) Distributional effects of climate change taxation: the case of the UK. Environ Sci Technol 44:3670-3676

Flanagan M, Schaechter A, Chelsky J, Gonzalez M, Halikias I, Ribakova E (2007) Ukraine: selected issues. International Monetary Fund. Available via DIALOG. http://www.imf.org/external/pubs/ft/scr/2007/ cr0747.pdf. Accessed 25 Aug 2012

Gangopadhyay S, Ramaswami B, Wadhwa W (2005) Reducing subsidies on household fuels in India: how will it affect the poor? Energy Policy 33:2326-2336

Ginsburgh V, Keyzer M (1997) The structure of applied general equilibrium models. MIT Press, Cambridge

Ho MS, Morgenstern R, Shih J (2008) Impact of carbon price policies on U.S. industry. Resources for the Future. Available via DIALOG. http://www.rff.org/rff/documents/rff-dp-08-37.pdf. Accessed 25 Aug 2012

IEA (1999) World energy outlook insights, looking at energy subsidies: getting the prices right. OECD Publishing, Paris

IEA (2004) Analysis of the impact of high oil prices on the global economy. OECD Publishing, Paris

IEA (2006a) World energy outlook. OECD Publishing, Paris

IEA (2006b) Ukraine: energy policy review. OECD Publishing, Paris

IEA (2008) World energy outlook. OECD Publishing, Paris

IEA (2011a) Key world energy statistics. OECD Publishing, Paris

IEA (2011b) Fossil fuel subsidy database. www.iea.org/subsidy/index.html. Accessed 25 Aug 2012

IEA (2012) Ukraine 2012: energy policies beyond IEA countries. IEA Publications, Paris

IER (2006) Macroeconomic impact of gas price shock. Available via DIALOG. http://www.ier.com.ua/ files/publications/Policy_papers/German_advisory_group/2006/V5_eng.pdf. Accessed 25 Aug 2012

IER (2007) Energy price shocks and market reforms: a quantitative assessment. Available via DIALOG. http://www.beratergruppe-ukraine.de/download/Beraterpapiere/2007/w3_en_Pavel_Energy\%20 price $\% 20$ shocks.pdf. Accessed 25 Aug 2012

ILO (2004) Consumer price index manual: theory and practice. International Labour Office, Geneva

Kebede B (2006) Energy subsidies and costs in urban Ethiopia: the cases of kerosene and electricity. Renew Energy 31:2140-2151

Kerkhof AC, Moll HC, Drissen E, Wilting HC (2008) Taxation of multiple greenhouse gases and the effects on income distribution: a case study of the Netherlands. Ecol Econ 67:318-326

Koplow D (2009) Measuring energy subsidies using the price-gap approach: what does it leave out? International Institute for Sustainable Development. Available via DIALOG. http://www.iisd.org/ pdf/2009/bali_2_copenhagen_ff_subsidies_pricegap.pdf. Accessed 25 Aug 2012

Lampietti J, Meyer A (2002) Coping with the cold, heating strategies for Eastern Europe and Central Asia's urban poor. Technical paper 529, World Bank, Washington, DC

Lampietti J, Kolb A, Gulyani S, Avenesyan V (2001) Utility pricing and the poor, lessons from Armenia. Technical paper 497, World Bank, Washington, DC

Lardic S, Mignon V (2006) The impact of oil prices on GDP in European countries: an empirical investigation based on asymmetric cointegration. Energy Policy 34:3910-3915

Larsen B, Shah A (1992) World energy subsidies and global carbon emissions. Research paper 1002, World Bank. Available via DIALOG. http://info.worldbank.org/etools/docs/library/206933/ WorldFossilFuelSubsidiesandGlobalCarbonEmissions.pdf. Accessed 25 Aug 2012

Legeida N (2001) Implicit subsidies in Ukraine: estimation, developments and policy implications. Institute for Economic Research and Policy Consulting. Available via DIALOG. http://www.ier.com.ua/ files/publications/WP/2001/Wp10_eng.pdf. Accessed 25 Aug 2012

Lin B, Jiang Z (2011) Estimates of energy subsidies in China and impact of energy subsidy reform. Energy Econ 33:273-283

Lovei L, Gurenko E, Haney M, O’Keefe P, Shkaratan M (2000) Maintaining utility services for the poor: policies and practices in Central and Eastern Europe and the former Soviet Union. World Bank, Washington

Miller RE, Blair PD (2009) Input-output analysis: foundations and extensions, 2nd edn. Cambridge University Press, Cambridge 
MENR (2010) National inventory of anthropogenic GHGs emissions and absorption. Available via DIALOG. http://unfccc.int/files/national_reports/annex_i_ghg_inventories/national_inventories_ submissions/application/zip/ukr-2011-nir-08jun.zip. Accessed 25 Aug 2012

MFE (2006) Energy strategy of Ukraine by 2030. Available via DIALOG. http://mpe.kmu.gov.ua/fuel/ control/uk/doccatalog/list?currDir=50505. Accessed 25 Aug 2012

MFE (2009) Annual report on development of fuel and energy complex of Ukraine. Available via DIALOG. http://mpe.kmu.gov.ua/fuel/control/uk/publish/article?art_id=146539\&cat_id=35081. Accessed 6 Oct 2011 (in Ukrainian)

Nahata B, Izyumov A, Busygin A, Mishura A (2007) Application of Ramsey model in transition economy: a Russian case study. Energy Econ 29:105-125

Nasseh AR, Elyasiani E (1984) Energy price shocks in the 1970s: impact on industrialized economies. Energy Econ 6:231-244

National Bank of Ukraine (2011) Official exchange rate of UAH (average for period). Available via DIALOG. http://www.bank.gov.ua/Statist/Stat_data/Exchange_r.xls. Accessed 30 July 2011

NERC (2009) Annual report of National Electricity Regulation Commission: 2008. Available via DIALOG. http://www2.nerc.gov.ua/control/uk/publish/article/main?art_id=81662\&cat_id=34446. Accessed 6 Oct 2011 (in Ukrainian)

OECD (2007) Financing water supply and sanitation in EECCA countries and progress in achieving the water-related millennium development goals. Available via DIALOG. http://www.oecd.org/ env/outreach/39174956.pdf. Accessed 25 Aug 2012

OECD (2010) Analysis of the scope of energy subsidies and suggestions for the G-20 Initiative. Background paper to the joint report by IEA, OPEC, OECD and World Bank. Available via DIALOG. http://www.oecd.org/dataoecd/62/63/45339216.pdf. Accessed 25 Aug 2012

Parvin S, Banouei AA (2009) Assessing the susceptibility of elimination in energy subsidies on the living standards of households in Iran. 17th International Input Output Conference, São Paulo, July 13-17. Available via DIALOG. http://www.iioa.org/conferences/17th/papers/ 622597991_090620_071301_PARVINANDBANOUEI.PDF. Accessed 25 Aug 2012

Perman R, Ma Y, Common M, Maddison D, Mcqilvray J (2003) Natural resource and environmental economics, 3rd edn. Pearson Education, Glasgow

Petri M, Taube G, Tsyvinski A (2002) Energy sector quasi-fiscal activities in the countries of the former Soviet Union. Working paper, IMF. Available via DIALOG. http://www.imf.org/external/ pubs/ft/wp/2002/wp0260.pdf. Accessed 25 Aug 2012

Pirani S (2007) Ukraine's gas sector. Oxford Institute for Energy Studies. Available via DIALOG. http://www.oxfordenergy.org/wpcms/wp-content/uploads/2010/11/NG21-UkrainesGasSectorSimonPirani-2007.pdf. Accessed 25 Aug 2012

Prosser RD (1985) Demand elasticities in OECD: dynamical aspects. Energy Econ 7:9-12

Russo C, Green RD, Howitt RE (2008) Estimation of supply and demand elasticities of California commodities. Department of Agricultural and Resource, Economics, UCD, UC Davis. Available via DIALOG. http://escholarship.org/uc/item/3432z1pv. Accessed 25 Aug 2012

Saavalainen T, Berge J (2006) Quasi-fiscal deficits and energy conditionality in selected CIS countries. Working paper 06/43, International Monetary Fund. Available via DIALOG. http://www.imf.org/ external/pubs/ft/wp/2006/wp0643.pdf. Accessed 25 Aug 2012

Saboohi Y (2001) An evaluation of the impact of reducing energy subsidies on living expenses of households. Energy Policy 29:245-252

Saunders M, Schneider K (2000) Removing energy subsidies in developing and transition economies. ABARE Conference paper 2000.14. 23rd Annual IAEE International Conference, International Association of Energy Economics, Sydney, June 7-10. Available via DIALOG. http://www.earthtrack.net/ files/Saunders_Schneider.pdf. Accessed 25 Aug 2012

Scrieciu SS (2007) The inherent dangers of using computable general equilibrium models as a single integrated modeling framework for sustainability impact assessment. A critical note on Bohringer and Loschel (2006). Ecol Econ 60:678

Soheir A, El-Laithy H, Kheir-El-Din H (2009) The impact of phasing out subsidies of petroleum energy products in Egypt. The Egyptian Center for Economic Studies. Available via DIALOG. http://www. eces.org.eg/Uploaded_Files/\%7B87C87F1A-6C8D-4A4D-BC46-18C15168AF13\%7D_ECES \%20WP145.pdf. Accessed 25 Aug 2012

SSCU (2009a) Statistical yearbook of Ukraine for 2008. SSCU, Kyiv (in Ukrainian)

SSCU (2009b) Household income and expenditures in Ukraine for 2008. SSCU, Kyiv (in Ukrainian)

SSCU (2009c) Fuel and energy resources of Ukraine. SSCU, Kyiv (in Ukrainian) 
SSCU (2010) Ukraine's input-output table at consumer prices for 2008. SSCU, Kyiv

UNEP (2004) Energy subsidies: lessons learned in assessing their impact and designing policy reforms. Available via DIALOG. http://www.unep.ch/etb/publications/energySubsidies/ Energysubreport.pdf. Accessed 25 Aug 2012

United Nations Statistics Division (2010) Carbon dioxide emissions. http://mdgs.un.org/unsd/mdg/ SeriesDetail.aspx?srid=749\&crid=. Accessed 25 Aug 2012

Wohlgemuth N (1997) World transport energy demand modeling: methodology and elasticities. Energy Policy 25:1109-1119

World Bank (1997) Expanding the measure of wealth: indicators of environmentally sustainable development. World Bank, Washington

World Bank (2005) Ukraine: the impact of higher natural gas and oil prices. Available via DIALOG. http://siteresources.worldbank.org/INTECAREGTOPENERGY/34004325-1112025344408/ 20772964/UkraineEnergyPricePolicyNote.pdf. Accessed 25 Aug 2012

World Bank (2012) Modernization of the district heating systems in Ukraine: heat metering and consumption-based billing. Report 64989-UA, Sustainable Development Department Europe and Central Asia Region. Available via DIALOG. http://siteresources.worldbank.org/ UKRAINEINUKRAINIANEXTN/Resources/455680-1332179461564/UkraineDHreport2012e.pdf. Accessed 1 June 2013 